\title{
Fracture of Shareholders' Rights to Participate in Management in Joint Stock Company: Establishment of Usufruct on the Share
}

\author{
Anonim Ortaklıkta Pay Sahibinin Yönetime Katılma Haklarında Kırılma: Pay Üzerinde \\ İntifa Hakkı Tesisi
}

\section{Esra Cenkci' 1 (1)}

\begin{abstract}
According to the provisions of property law, the usufruct grants the owner the power to possess, manage, use and benefit from the subject of the usufruct. This study determines how these powers will spread to rights to participate in management arising from the company's share when the subject of the usufruct is a share of a joint stock company. The issue is handled in the center of article $432 \mathrm{II}$ of the Turkish Commercial Code. The Turkish Commercial Code differs from the provisions of the Swiss Code of Obligation 690 II and the Turkish Commercial Code numbered 6762 in certain points and regulates that the voting right arising from the share which has usufruct on it is used by the usufructuary, but the usufructuary shall be liable for any loss incurred when he / she does not respect the interests of the shareholder.
\end{abstract}

When evaluated together with the rules of property law, this study concludes that the provision brings a regulation in terms of voting rights; the usufructuary who has voting rights can also use other rights to participate in management, thus taking over the management of the share. However, the shareholder is not completely ineffective in this case. Some of the rights to participate in the management can also be used by the shareholder. Nevertheless, this does not include the right to file an annulment action, which is at least as effective as the voting right.

This study also discusses whether the shareholder can maintain his or her authority over the share, despite there being a usufruct on the share, by stipulating otherwise in the articles of association or an agreement between parties.

\section{Keywords}

Share of joint stock company, usufruct, voting right, right to attend assembly general meetings, right to demand information, right to file an annulment action

\section{Öz}

Eşya hukukuna ilişkin hükümler uyarınca intifa hakkı, sahibine, intifa konusunu zilyetliğinde bulundurma, yönetme, kullanma ve ondan yararlanma yetkilerini tanımaktadır. Bu çalışmada, intifa hakkının konusu anonim ortaklık payı olduğunda anılan yetkilerin ortaklık payından doğan yönetime katılma haklarına nasıl sirayet edeceği incelenmektedir. Konu, Türk Ticaret Kanunu 432 II merkezinde ele alınmaktadır. Türk Ticaret Kanunu bu konuda gerek mehaz İsviçre Borçlar Kanunu 690 II hükmünden gerekse 6762 sayılı Türk Ticaret Kanunu’ndan bazı noktalarda ayrılarak üzerinde intifa hakkı bulunan paydan doğan oy hakkının intifa hakkı sahibi tarafından kullanılacağını; pay sahibinin menfaatlerini gözetmeyen intifa hakkı sahibinin tazminat sorumluluğunun doğacağını düzenlemektedir.

Eşya hukuku kuralları ile birlikte değerlendirildiğinde hükmün oy hakkı açısından bir düzenleme getirdiği; oy hakkına sahip olan intifa hakkı sahibinin diğer yönetime katılma haklarını da kullanabildiği ve böylece payın yönetiminin intifa hakkı sahibinde olduğu sonucuna ulaşılmaktadır. Öte yandan, pay sahibi bu durumda tamamen etkisiz değildir; yönetime

1 Corresponding Author: Esra Cenkci (Assoc. Prof. Dr.), Akdeniz University, Faculty of Law, Department of Commercial Law, Antalya, Turkey. E-mail: esracenkci@akdeniz.edu.tr ORCID: 0000-0001-5396-1591

To cite this article: Cenkci E, "Fracture of Shareholders' Rights to Participate in Management in Joint Stock Company: Establishment of Usufruct on the Share", (2021) 70 Annales de la Faculté de Droit d'Istanbul 1. https://doi.org/10.26650/annales.2021.70.0109 
katılma haklarının bazıları pay sahibi tarafından da kullanılabilmektedir. Ne var ki, bu kapsama en az oy hakkı kadar etkili bir hak olan iptal davası açma hakkı dahil değildir.

Çalışmada ayrıca, esas sözleşmede veya özel bir anlaşmada hükmün aksinin öngörülerek payın üzerinde intifa hakkı bulunmasına rağmen pay sahibinin payı üzerindeki otoritesini sürdürüp sürdüremeyeceği de tartışılmaktadır.

\section{Fracture of Shareholders' Rights to Participate in Management in Joint Stock Company: Establishment of Usufruct on the Share}

\section{Introduction}

According to the Swiss Code of Obligation ${ }^{1}$ (SCO) 690 II, when a usufruct exists on a share, it is represented by the usufructuary, but the usufructuary who does not respect the interests of the shareholder shall be liable for any loss against her / him. The provisions of Turkish law on this subject were taken from Swiss law SCO 690 II and was transferred to Turkish Commercial Code $^{2}$ (TCC) 432 II with small differences. According to the aforementioned provision, when there is a usufruct on the share, unless otherwise agreed, the voting right is used by the usufructuary. The usufructuary is responsible to the shareholder when he / she does not respect the interests of the shareholder.

The subject of the usufruct on the share is the rights provided by the share ${ }^{3}$. There is no doubt that the main interest of usufructuary is for financial rights ${ }^{4}$. However, considering that management rights, voting rights, the right to attend assembly general meetings, and the right to demand information and right to file an annulment action can all be considered within the scope of the usufruct, constitutes an important problem. The provision in the Code (SCO 690 II, TCC 432 II) is insufficient to provide a solution to this problem, as the code requires that the rules regarding company law and property law are taken into account.

1 Federal Act of 30 March 1911 on the Amendment of the Swiss Civil Code (Part Five: The Code of Obligations).

2 Turkish Commercial Code, Code Number: 6102, Acceptance Date: 13.1.2011, Official Gazette 14.2.2011/27846.

3 Martin Bichsel and Kaspar Mauerhofer, in Jolanta Kren Kostkiewicz, Stephen Wolf, Marc Amstutz and Roland Frankhauser (eds), ZGB Kommentar (3rd edn, Orell Füssli 2016) Art 745 N 11; Walter Boss, in Jolanda Kren Kostkiewicz, Stephen Wolf, Marc Amstutz and Roland Fankhauser (eds), OR Kommentar (3rd edn, Orell Füssli 2016) Art 690 N 6; Stephan Dekker, in Jeannette K. Wibmer (ed), Aktienrecht Kommentar: Aktiengesellschaft, Rechnungslegungsrecht, VegüV, GeBüV, VASR (1st edn, Orell Füssli 2016) Art 690 N 11; Peter Forstmoser, Arthur Meier-Hayoz and Peter Nobel, Schweizerisches Aktienrecht (1st edn, Stämpfli 1996) § 45 N 13; Abuzer Kendigelen, Anonim Ortaklık Payl Üzerinde Intifa Hakkl (1st edn, Beta 1994) 28; Andreas Länzlinger, in Heinrich Honsell, Nedim Peter Vogt and Rolf Watter (eds), Basler Kommentar: Obligationenrecht II Art. 530-964 OR inkl. Schlussbestimmungen (5th edn, Helbing Lichtenhahn 2016) Art 690 N 12; Alain Raemy and Simon Gabriel, in Vito Roberto and Hans Rudolf Trüeb (eds), Handkommentar zum Schweizer Privatrecht Bd. 7: Personengesellschaften und Aktiengesellschaft - Vergütungsverordnung [Art. 530-771 OR und VegüV] (3rd edn, Schulthess 2016) Art 690 N 7; Christoph Thurnherr, in Peter Breitschmid and Alexandra Jungo (eds), Handkommentar zum Schweizer Privatrecht Bd 3: Sachenrecht Art. 641-977 ZGB (3rd edn, Schulthess 2016) Art 745 N 4.

4 Werner Weber, Das Stimmrecht bei Aktien in Nutzniessung (J. Kalt-Bucher 1927) 52. 
This study will attempt to determine the distribution of authority between a shareholder and a usufructuary in respect to the use of the management rights provided by a share. Financial rights such as the right to demand dividend, liquidating dividends, pre-emptive rights and so on are not in the scope of this study. While doing this, the Swiss and the Turkish law literature and practice will be used.

\section{Usufruct in General}

Usufruct is an easement which allows a certain person full benefits of a property, right or estate. In this respect, usufruct is a limited real right that provides the widest authority on the subject of usufruct in favor of a person after the owner. In fact, through the establishment of usufruct, the naked ownership or the eigenvalue of property or right remains in the possession of the owner. The power to possess, manage, use this right or property and benefit from it belongs to a certain person ${ }^{5}$. Even though the parties may agree to exclude the authority to benefit in certain matters from the usufruct ( $\mathrm{SCivC}^{6} 745 \mathrm{II}, \mathrm{TCivC}^{7} 794 \mathrm{II}$ ), the authority to benefit from the usufruct should belong to the usufructuary in its widest scope ${ }^{8}$. The usufructuary has to exercise care as a good manager when using his or her powers (SCivC 755 III, TCivC 803 II).

It is possible to establish a usufruct, either by an agreement between the shareholder and the usufructuary, or in connection with the use of a right arising from the law; also, the surviving spouse can ask for a usufruct on the residence where they lived with the deceased spouse (SCivC 612a, TCivC 652 II) 9

\section{Establishment of Usufruct on the Share}

Shares of a joint stock company may also be subject to the usufruct. The fact that the share is tied to a bill does not change the fact that the subject of the usufruct is a right; it is only important for the formal transactions required to establish usufruct on the share ${ }^{10}$. That is to say, the promissory transaction to establish usufruct on the share is not subject to a form. However, the disposal transaction takes place in accordance with rules regarding the transfer of the negotiable instruments when the share is tied to a bill. Accordingly, the registered shares should be endorsed, and their possession should be transferred (SCO 967 I II, TCC 490 II). Including the statement "for usufruct" in the endorsement transaction prevents the usufructuary from transferring the bill as if he is

5 Bichsel and Mauerhofer (n 3) Art 745 N 13; Kemal Oğuzman, Özer Seliçi and Saibe Oktay-Özdemir, Eşya Hukuku (14th edn, Filiz 2011) 662, 694, 679.

6 Swiss Civil Code of 10 December 1907.

7 Turkish Civil Code, Code Number: 4721, Acceptance Date: 22.11.2001, Official Gazette 8.12.2001/24607.

8 Bichsel and Mauerhofer (n 3) Art 745 N 8, Art 755 N 1; Bülent Köprülü and Selim Kaneti, Sinırlı Ayni Haklar (Fakülteler Matbaası 1972-1973) 97; Oğuzman, Seliçi and Oktay-Özdemir (n 5) 661; Thurnherr (n 3) Art 745 N 5.

9 For the view that the legal usufruct cannot be qualified as narrow and technically usufruct, as they have different features than the usufruct arising from an agreement, see: Köprülü and Kaneti (n 8) 85.

10 Köprülü and Kaneti (n 8) 83; Kendigelen (n 3) 29. 
an owner against third parties in good faith ${ }^{11}$. It is sufficient to transfer the possession of the bearer shares in order to establish usufruct on them ${ }^{12}$.

Restrictions imposed by the articles of association regarding the transfer of registered shares also go for the usufruct (SCO 685a II, TCC 492 II). In this case, usufruct on a share can only be established with the approval of the company (SCO 685a I, TCC 492 I).

Usufructuaries are also registered in the book of shares. In relations with the company, usufructuaries, which are registered in the book of shares, are accepted as rights holders (SCO 686 IV, TCC 499 III). However, since the registration in the book of shares does not have a constitutive effect in terms of gaining entitlement, the usufructuary who proves this title in other ways may also use his rights against the company.

\section{Distribution of Rights to Participate in Management}

\section{A. Voting Rights}

\section{As a Rule: Use of Voting Rights by the Usufructuary}

A vote is a unilateral declaration of intention that enables the shareholder to participate in the will of the company. Although the shareholder has only one share, he has at least one voting right (SCO 692 II, TCC 434 II). This "minimum voting right" is an inalienable shareholder right (SCO 707b I 1, TCC 447 I a). Aforesaid nature of the voting right contradicts the rights of usufructuary. It is stated in the SCO 690 II that the share which has usufruct on it will be represented ("vertreten") by the usufructuary ${ }^{13}$. The TCC includes a provision on the subject of voting rights. Accordingly, voting rights arising from the share which has usufruct on it is used by the usufructuary (TCC 432 II). In this case, voting rights are used directly as a rightsholder by the usufructuary, but not as a representative of the shareholder ${ }^{14}$.

11 Max Baumann, 'Nutzniessung und Wohnrecht, Art. 745-778 ZGB' in Peter Gauch and Jörg Schmid (eds), Zürcher Kommentar ZGB Band IV/2a/2 - Das Sachenrecht - Die beschränkten dinglichen Rechte (3rd edn, Schulthess 1999) Art 773, 774, 775 / A. - C. N 20; Weber (n 4) 26.

12 Baumann, 'Nutzniessung und Wohnrecht' (n 11) Art 773, 774, 775 / A. - C. N 21; Kendigelen (n 3) 87, 94; Köprülü and Kaneti (n 8) 81, 83; Oğuzman, Seliçi, Oktay-Özdemir (n 5) 664; Yiğit Tahsin Okur, 'Hisse Senetleri Üzerinde İntifa Hakk1 Tesisi' (1971) 18(6) İktisat ve Maliye Dergisi 224, 224 ff; Weber (n 4) 26. For the view that an annotation like "for usufruct" on the bearer share will eliminate the good faith of third parties see: Baumann, 'Nutzniessung und Wohnrecht' (n 11) Art 773, 774, 775 / A. - C. N 21.

13 Since there was no provision about this issue before SCO 690 II, for different opinions see Weber (n 4) $36 \mathrm{ff}$. The Federal Court decided (50 II $545 \mathrm{ff}$ ) that voting rights should be used by the shareholder and usufructuary together, such as coowners on the share before the article 690 II of the SCO came into force.

14 Forstmoser, Meier-Hayoz and Nobel (n 3) § 45 N 13-14; Sandro Germann, Die personalistische AG und GmbH - Unter besonderer Berücksichtigung von Aktionär- und Gesellschafterbindungsverträgen, SSHW Band/Nr. 327 (Dike 2015) N 663; Peter Jung, in Lukas Handschin (ed), Zürcher Kommentar: Allgemeine Bestimmungen, Art. 620-659b OR Die Aktiengesellschaft, (2nd edn, Schulthess 2016) 625 N 67; Kendigelen (n 3) 207 ff; Erdoğan Moroğlu, 'Anonim Ortaklıkta Genel Kurul' in Erdoğan Moroğlu (ed), Makaleler (On İki Levha 2010) 291, 299-302; Ömer Teoman, 'Anonim Ortaklıkta Paylar Üzerinde İntifa Hakkı Bulunması Durumunda Oy Hakkı Dışındaki Yönetim Haklarının Kimin Tarafından Kullanılacağı Sorunu' in Ömer Teoman (ed), Tüm Makalelerim, vol. I-II: 1971-2001 (2nd edn, On İki Levha 2012) 365, 373. Jung, entitles the usufructuary who has voting right as de facto shareholder ("Quasi-Aktionär") (Jung ibid Art 625 N 93). 
The use of the expression "vertreten", which means "represent" in the SCO does not change this result ${ }^{15}$. Thus, an exception is made to the rule that the minimum voting right is an inalienable shareholder right.

The fact that the voting right belongs to the usufructuary is based on the fact that this right is an important tool in using the power to manage provided by the usufruct ${ }^{16}$. According to a view against this, the use of the voting right is a management process aimed at benefiting from the fruits of the share; however, its legal effect is in any case closely related to the eigenvalue of the share. Since this circumstance exceeds the limits of the power to manage and benefit which is granted to the usufructuary to obtain the fruits, the voting right should not be considered within the scope of the power to manage ${ }^{17}$. In my opinion, the fact that the interests of the shareholder regarding the eigenvalue of the share will be adversely affected when the voting right is used by the usufructuary is a matter that can be considered in terms of the appropriateness of granting the voting right to the usufructuary. However, this does not prevent the voting right from being evaluated within the scope of the power to manage.

When it comes to the matter of whether granting the voting right to the usufructuary is the most appropriate when the balance of interests is considered, Kendigelen asserts that the provision of TCC 432 II (SCO 690 II) does not bring a correct solution. According to him, the voting right is of equal importance for both the shareholder and the usufructuary; however, the interest of the shareholder acting for the purpose of protecting the assets and value of the share is fundamental in face of the interest of the usufructuary acting only for profit. Furthermore, the majority of the decisions taken at the assembly general meeting are related to the eigenvalue of the share and they concern the interests of the shareholder. The principle of liability that will apply when the voting right is used in a way that disregards the interests of the other party is more applicable when the voting right is used by the shareholder. In this respect, the interests of the shareholder can only be protected when the voting right is granted to the shareholder and, in this case, an adequate protection can also be provided for rights of the usufructuary ${ }^{18}$. In case the usufruct is established on a share, interests

15 Peter Böckli, Schweizer Aktienrecht mit Fusionsgesetz, Börsengesellschaftsrecht, Konzernrecht, Corporate Governance, Recht der Revisionsstelle und Abschlussprüfung in neuer Fassung - unter Berücksichtigung der angelaufenen Revision des Aktien- und Rechnungslegungsrechts (4th edn, Schulthess 2009) § 12 N 137; Forstmoser, Meier-Hayoz and Nobel (n 3) § 45 N 13; Jung (n 14) Art 625 N 67; Länzlinger (n 3) Art 690 N 12.

16 Baumann, 'Nutzniessung und Wohnrecht' (n 11) Art 773, 774, 775 / A. - C. N 41; Boss (n 3) Art 690 N 8; Botschaft des Bundesrates an die Bundesversammlung zu einem Gesetzesentwurf über die Revision der Titel XXIV bis XXXIII des schweizerischen Obligationenrechts vom 21. Februar 1928 (BB1 1928 I 205) 246; Dekker (n 3) Art 690 N 11 15; Forstmoser, Meier-Hayoz and Nobel (n 3) § 45 N 13; Länzlinger (n 3) Art 690 N 12; Arzu Oğuz, 'Pay Senetleri Üzerinde İntifa Hakkı Kurulması ve İntifa Hakkının Kapsamı'(1991) (1) Ankara Barosu Dergisi 23, 37; Yiğit Tahsin Okur, 'Üzerinde Kısmen İntifa Hakkı Tesis Olunmuş Hisse Senetlerinden Doğan Oy Hakkının Kime Ait Olacağı' (1971) 18(7) İktisat ve Maliye Dergisi 273, 274; Raemy and Gabriel (n 3) Art 690 N 7 10; Thurnherr (n 3) Art 755 N 3.

17 Kendigelen (n 3) 236-240.

18 Kendigelen (n 3) 240-248. On the same page, see Weber (n 4) $51 \mathrm{ff}$. 
of the parties conflict, because the interest of usufructuary is to benefit from the fruits of the share to the maximum while the interest of the shareholder is to protect the eigenvalue of the share. Taking into consideration the nature of usufruct, the usufructuary is charged with not harming the eigenvalue of the share while using his rights and thus an attempt at a balance was made between these conflicting interests (SCO 690 II, TCC 432 II). This charge prevents the unrestricted use of the voting right by the usufructuary, when the decision to be taken at the assembly general meeting concerns the eigenvalue of the share ${ }^{19}$. Therefore, the use of the rights by the usufructuary on the condition that not harming the eigenvalue of the share would not cause the usufructuary to be isolated from the power to manage the share; on the contrary, this restriction imposed on the power of the usufructuary ensures the use of the power to manage by himself. Under this requirement lies the thought that general meeting resolutions regarding the eigenvalue of the share also affect the right to the benefits of the usufructuary in some way. For example, although the decision for a merger is a decision concerning the eigenvalue of the share, the results of the merger affect the fruits of the share, which are the most important interest of the usufructuary. Moreover, even if individual interests conflict, the common interest of the shareholder and usufructuary is the growth and the maximum profit of the company. As such, the results of the right to manage used by the usufructuary in decisions concerning the eigenvalue of the share will generally be in the interest of the shareholder.

On the other hand, the preferences of the usufructuary on matters concerning the eigenvalue of the share may not always serve the common interest. Since the usufructuary will focus on the short-term results of the decision taken while using the voting right, the decision may have a negative effect on interests of shareholders in the long term. There are provisions to protect shareholders against this danger. Firstly, a legal relationship arises between the usufructuary and the shareholder when the usufruct is established ${ }^{20}$. The breach of this relationship, which necessitates the protection of the eigenvalue and the prudent management of the share by the usufructuary, is the reason for liability (SCivC 752, $\mathrm{SCO} 97, \mathrm{TCO}^{21} 112$ ). This point is enacted in SCO 690 II and TCC 432 II exclusively for the use of voting rights ${ }^{22}$. A shareholder may also benefit from general provisions regarding usufruct: He may contest the use of the voting right in violation of his interest; on condition that he proves that his rights fell into danger, he may request assurance from the usufructuary (SCivC 759, 760, TCivC 807, 808). If the usufructuary does not provide assurance or does not end the unlawfulness, the shareholder may litigate for the immediate

19 Raemy and Gabriel (n 3) Art 690 N 10.

20 Kendigelen (n 3) 117; Köprülü and Kaneti (n 8) 68.

21 Turkish Code of Obligations, Code Number: 6098, Acceptance Date: 11.1.2011, Official Gazette 4.2.2011/27836.

22 Baumann, 'Nutzniessung und Wohnrecht' (n 11) Art 773, 774, 775 / A. - C. N 41. 
transfer of the management of the share to the trustee (SCivC 762, TCivC 810). As can be seen, the power to manage has been granted to the usufructuary in accordance with the definition and nature of the usufruct by both general and special provisions. The usufructuary's power to manage in matters related to the eigenvalue is limited and preventive measures are taken to protect the shareholder against the risk of a breach of this limit.

\section{As an Exception: Use of the Voting Right by the Shareholder}

When there is a usufruct on a share, the rule that the voting right will be used by the usufructuary is not mandatory ${ }^{23}$. Unlike the SCO, it is explicitly stated in the TCC with the expression "if not otherwise agreed". Therefore, parties may make an agreement that is different from the legal regulation and serves the interests of both parties $^{24}$. The shareholder and the usufructuary may agree that the voting right will be used by the shareholder ${ }^{25}$. It is not necessary to have a provision in the articles of association to make such an agreement ${ }^{26}$. This agreement which is not subject to a form $^{27}$ is relatively effective between parties $^{28}$.

Leaving the voting right to the shareholder means that the power to manage is exercised by the shareholder. Changing of the content of the usufruct in this way does not contradict the nature of limited real rights and the rule that limited real rights are subject to the type restriction, because the provisions related to the property law allow for such a change within the scope of the usufruct (SCivC 745 II, 755 II, TCivC 794 II, 803). As stated above, since the primary interest of the usufructuary is to benefit from fruits of the share, the usufruct focuses on shareholding rights related to assets. Thus, the use of the voting right by the shareholder does not harm the core of the usufruct.

When it comes to the matter of whether articles of association can include a provision stating that the voting right will be used by the shareholder, According to

23 Zühtü Aytaç, Sermaye Piyasası Hukuku ve Hisse Senetleri (BTHAE 1988) 122-123; Herald Bärtschi, 'Pfandrecht und Nutzniessung an Gesellschaftsanteilen' in Peter V. Kunz, Florian S. Jörg and Oliver Arter (eds), Entwicklungen im Gesellschaftsrecht VII (Stämpfli 2012) 338; Kendigelen (n 3) 257 ff; Rudolf Koeferli, Die Nutzniessung an Wertpapieren unter besonderer Berücksichtigung der Nutzniessung an Aktien (P.G. Keller 1954) 77; Oğuz (n 16) 36-37; Jung (n 14) Art $625 \mathrm{~N} 64 \mathrm{ff}$.

24 For the view that such an agreement is inevitable in order to protect the interests of both parties, see: Baumann, 'Nutzniessung und Wohnrecht' (n 11) Art 773, 774, 775 / A. - C. N 43. For a view that such an agreement would be against the principle of indivisibility of the share, see: Weber (n 4) 59.

25 Aytaç (n 23) 123; Bärtschi (n 23) 338; Boss (n 3) Art 690 N 9; Dekker (n 3) Art 690 N 13; Forstmoser, Meier-Hayoz and Nobel (n 3) § 45 N 23; Kendigelen (n 3) 260; Länzlinger (n 3) Art 690 N 13; Oğuz (n 16) 36-37; Raemy and Gabriel (n 3) Art $690 \mathrm{~N} 8$.

26 Jung (n 14) Art 625 N 66.

27 Kendigelen (n 3) 268-269; Hüseyin Ülgen, 'Anonim Ortaklıklarda Paylar Üzerinde İntifa Hakkı Halinde Oy Hakkının Malik Tarafından Kullanılmasını Öngören Sözleşmelerin Geçerliliği’ (1977) 28(12) İktisat ve Maliye Dergisi 488, 495; Weber (n 4) 59. 
Böckli, changes regarding the voting right within the corporate area of the company can only be made by the articles of association. Unless there has been a provision contrary to SCO 690 II in the articles of association, such an agreement, which is relatively effective between parties, cannot be claimed against the company; with this agreement, all that can be said is that the shareholder has been authorized to use the voting right ${ }^{29}$. Another view is that it is not compulsory to have a provision in the articles of association; however, this issue can be foreseen in the articles of association as well as in an agreement between parties ${ }^{30}$. The reasons Koeferli offers, are remarkable. According to him, parties can freely agree on this issue since there is no public interest in using voting rights by the usufructuary and there is no prohibition in entitling the shareholder to vote by the usufructuary. In addition, since the company has sovereignty in determining its organization, voting rights can be bestowed to the shareholder through the articles of association ${ }^{31}$. It should be emphasized that there is no explicit provision in the SCO that the articles of association may include a provision contrary to the SCO 690 II. Indeed, the expression "voting right of shareholders" in the SCO 626 (I 5), where the mandatory content of the articles of association is regulated, refers to the regulation to limit voting rights of those holding more than one share (SCO 692 II) and the regulation regarding that each share has one vote, regardless of its nominal value (SCO 693). These are also considered to be included in conditionally mandatory content (SCO $62710)^{32}$. Therefore, the legal order does not allow for such a provision in the articles of association ${ }^{33}$. In addition, issues related to the corporate area of the company are issues such as limitation of voting rights and privileges in voting. Since the use of voting rights by the usufructuary or the shareholder is not in the scope of the corporate area, it is not compulsory to have a basis in the articles of association. Acceptance of the opposite view requires that a provision should also be sought in the articles of association for an appointment of a representative. Besides, the right to change the content of the agreement between the shareholder and the usufructuary regarding the establishment of usufruct on the share belongs to parties of this relationship to the

29 Böckli (n 15) § 12 N 137; Jung (n 14) Art 625 N 67.

30 Bärtschi (n 23) 338; Boss (n 3) Art 690 N 9; Dekker (n 3) Art 690 N 13; Forstmoser, Meier-Hayoz and Nobel (n 3 ) § 45 N 23; Länzlinger (n 3) Art 690 N 13.

31 Koeferli (n 23) 77-78.

32 Böckli (n 15) § 1 N 484 500; Wolfgang Zürcher, in Jolanda Kren Kostkiewicz, Stephen Wolf, Marc Amstutz and Roland Fankhauser (eds), OR Kommentar (3rd edn, Orell Füssli 2016) Art 626 N 11; Adrian Plüss, in Jeannette K. Wibmer (ed), Aktienrecht Kommentar: Aktiengesellschaft, Rechnungslegungsrecht, VegüV, GeBüV, VASR (1st edn, Orell Füssli 2016) Art 626 N 5; Conradin Cramer, in Lukas Handschin (ed), Zürcher Kommentar: Allgemeine Bestimmungen, Art. 620$659 b$ OR Die Aktiengesellschaft (2nd edn, Schulthess 2016) Art 626 N 49; Martin Waldburger, in Vito Roberto and Hans Rudolf Trüeb (eds), Handkommentar zum Schweizer Privatrecht Bd. 7: Personengesellschaften und AktiengesellschaftVergütungsverordnung [Art. 530-771 OR und VegüV] (3rd edn, Schulthess 2016) Art 626 N 9.

33 On the other hand, Jung argues that the conditional mandatory content regulated in SCO 627 is not limited to those listed in this article (see for the same view: Böckli (n 15) § 1 N 508; Cramer (n 32) Art 627 N 24; Waldburger (n 32 ) Art 627 N 1); hence, the fact that the use of voting right arising from the share which has usufruct on it is not stated in SCO 627 does not mean that there can bring no provision in the articles of association in this matter; nevertheless, such a provision, which will later be included in the articles of association, must be approved by the usufructuary [Jung (n 14) Art $625 \mathrm{~N}$ 64]. 
extent permitted by law. Thereby, the relativity of the agreement prevents inserting provisions that will affect this relationship in the articles of association. The desire to include such a provision in the articles of association may arise from the idea of protecting the economic independence of the company by preventing interference in its management. The way that the company can achieve this is regulated in the TCC 492 II (SCO 685a II). Accordingly, an establishment of usufruct may be subject to an approval of the company by a provision in the articles of association ${ }^{34}$. TCC 492 II (SCO 685a II) stipulates that the power of the company to establish usufruct on shares is not unlimited; the right to attend the assembly general meeting and the voting right of the usufructuary can only be prevented by the company in certain cases. Therefore, the company cannot prevent the use of the voting right by the usufructuary through a general provision stipulated in the articles of association ${ }^{35}$.

It is also possible to distribute voting rights between the usufructuary and the shareholder on the basis of a variety of matters ${ }^{36}$. For example, it may be decided that the voting right belongs to the shareholder in matters related to the change of structure and capital, but it shall be used by the usufructuary in other matters. Since there is no simultaneous use or demand for the same right by more than one person, such an agreement does not contradict the principle of the indivisibility of shares. Parties may also agree that a part of voting rights arising from the shares that are subject to the usufruct shall be used by the shareholder and the remaining portion by the usufructuary ${ }^{37}$. Although it is theoretically possible to make an agreement that the voting right shall be used together, it will be in the interest of neither the company nor the parties if they cannot agree on matters where their interests conflict and that this situation is continuous ${ }^{38}$.

The possibility of making an agreement on the use of voting rights between parties brings the problem of how the company shall determine who is entitled to use the voting right. As it is known, besides registered shareholders, usufructuaries are also registered in the book of shares, and the person who has been registered in the book of shares is accepted as a shareholder or a usufructuary (SCO 686 I IV, TCC 499 IV). The reason for the usufructuaries also being registered in the book of shares is that the authority to represent the share is given to the usufructuary with the SCO 690 II (TCC

34 On this subject, see Hanspeter Kläy, Die Vinkulierung, Theorie und Praxis im neuen Aktienrecht Helbing \& Lichtenhahn 1997) 308, 511 ff; Thomas Nagel, 'Die statutarische Vinkulierung nicht kotierter Namenaktien' (2015) (1) AJP/PJA 191, 196-197.

35 For the view that the voting right cannot be given to the shareholder by the articles of association, see: Kendigelen (n 3 ) 266-267; Okur, 'Oy Hakk1' (n 16) 274-275.

36 Aytaç (n 23) 123; Max Baumann, Praktische Probleme der Nutzniessung an Aktien, Obligationen und AnlagefondsAnteilscheinen (Schulthess Polygraphischer 1980) 53; Kendigelen (n 3) 265.

37 Baumann, Nutzniessung an Aktien (n 36) $55 \mathrm{ff}$.

38 Botschaft des Bundesrates an die Bundesversammlung zu einem Gesetzesentwurf über die Revision der Titel XXIV bis XXXIII des schweizerischen Obligationenrechts vom 21. Februar 1928 (BB1 1928 I 205) 246; Koeferli (n 23) 75; Weber (n 4) 46, 49-51. 
432 II) and shareholding rights arising from the registered shares can be used by the persons registered in the book of shares (SCO 689a). Therefore, the company should be notified that the voting right is left to the shareholder by an agreement, or the issues for which the shareholder is entitled to vote, and this should be recorded in the book of shares ${ }^{39}$. Since these records have a reporting effect, it should not be forgotten that it can be claimed against the company by proving the right-holding in other ways. Although the notified company did not comply with this, and did not do the necessary transactions, an annulment action can be filed for decisions of the assembly general meeting (SCO 706, TCC 446). When the agreement regarding the use of the voting right is not notified to the company or the entitlement cannot be proved, esteeming of the company to the legal regulation should be justified, as the shareholder must suffer the consequences of not fulfilling the obligation of notification or burden of proof.

The shareholder uses the voting right obtained by the agreement directly as a right holder, not as a representative $\mathrm{e}^{40}$. When using the voting right, the shareholder has to comply with obligations arising from the legal relationship that causes the usufruct on the share. Hereunder, the shareholder should act taking into consideration rights of the usufructuary; otherwise, he is obliged to pay damages to the usufructuary (SCO 97, TCO 112).

\section{Use of the Voting Right in Case the Share is Partially Subject to the Usufruct}

The question of who will use the voting right arising from the share that is partially subject to usufruct is disputable. According to Kendigelen, when interests are compared, the voting right should belong to the shareholder if the usufruct is $50 \%$ or less, but if it exceeds $50 \%$ of the share, the provision of law (SCO 690 II, TCC 432 II) should be applied by analogy and the voting right should be used by the usufructuary ${ }^{41}$. In Turkey, the Supreme Court of Appeals has decided that the voting rights arising from the shares that are subject to the usufruct belong to the usufructuary by law ${ }^{42}$ (TCC 432 II). TCC 432 II (SCO 690 II) has the purpose of granting the voting right to the usufructuary based on reasons that interests of the usufructuary should be protected against the shareholder who is in a stronger position. Thus, the shareholder is already protected against dangers arising from the use of voting rights by the usufructuary with the same provision ${ }^{43}$; the use of the voting rights by the usufructuary is not regulated depending on a proportion in the

\footnotetext{
39 Kendigelen (n 3) 265-266, 269; Ülgen (n 27) 495.

40 Kendigelen (n 3) 261; Ülgen (n 27) 495

41 Kendigelen (n 3) 256-257.

42 Eleventh Civil Department of the Supreme Court of Appeals, 2243/2768, 28.5.1981 < www.sinerjimevzuat.com.tr > accessed 15 February 2019; Second Business Department of the Supreme Court of Appeals, 3004/, 30.3.1973 [Hayri Domaniç, Anonim Şirketler Hukuku ve Uygulaması - TTK Şerhi II (Temel 1988) 791-792]. 
law ${ }^{44}$. In this case, since there is more than one right on a share, it is conceivable that the voting right can be used through a joint representative ${ }^{45}$, but conflicting interests of the usufructuary and the shareholder prevent them from demonstrating their will through a joint representative. This is because conflicting interests, aside from the appointment and dismissal of the representative, also bring uncertainties about how the representative will perform the different orders ${ }^{46}$.

In my opinion, the will of the shareholder, who permits partial usufruct on his share, is different from the establishment of a usufruct on the whole share. The shareholder does not want to lose control of the share in this way and the usufructuary implicitly accepts the authority of the control of the shareholder by consenting to obtain usufruct partially. In this respect, when the usufruct right is partially established on a share, TCC 432 II (SCO 690 II) which brings an exception to the shareholder's voting right should not be applied; it shall be accepted that the voting right belongs to the shareholder by respecting the will of the parties which can be seen in the agreement between them. In this case, the shareholder does not use the voting right as a representative of the usufructuary; he uses the voting right as a right holder. While using this right, the shareholder is obliged to comply with the provisions of the legal relationship with the usufructuary, while at the same time, being obliged not to violate the right to benefit of the usufructuary. Otherwise, he has to pay the damages of the usufructuary (SCO 97, TCO 112).

When a share is subject to more than one usufruct, the discussions above have no place because of the harmony of the interests of right holders. In this case, voting rights provided by shares should be used through a joint representative ${ }^{47}$.

\section{B. Right to Attend Assembly General Meetings}

Since the voting right can be used in the assembly general meetings, the usufructuary who is authorized to use the voting right, also has the right to attend assembly general meetings ${ }^{48}$. The fact that TCC 432 (SCO 690) is regulated under the heading of "I-Attendance to the assembly general meeting" confirms this. The right to attend assembly general meetings includes the right to participate in discussions in the assembly general meeting a fortiori.

There are different opinions in the doctrine whether or not the shareholder can also attend assembly general meetings, when the voting right is used by the usufructuary. According to some, when the voting right belongs to the usufructuary, the shareholder

44 Aytaç (n 23) 122; Oğuz (n 16) 39.

45 Indeed, see: Domaniç (n 42) 784.

46 Kendigelen (n 3) 252; Oğuz (n 16) 39; Okur, 'İntifa Hakkı' (n 12) 277-278.

47 Aytaç (n 23) 123; Domaniç (n 42) 784; Kendigelen (n 3) 253; Oğuz (n 16) 39.

48 Bärtschi (n 23) 337; Jung (n 14) Art 625 N 67; Kendigelen (n 3) 326; Moroğlu, 'Genel Kurul' (n 14) 299 ff; Teoman (n 14 ) 374. 
does not have the right to attend assembly general meetings ${ }^{49}$. Holders of this view do not state any explicit reason for their view. Contrarily, others argue that as it is understood from the marginal heading of the SCO 689 (TCC 425), this provision aims not to jointly use a part of rights flowing from attendance to the assembly general meeting. For this reason, in this case, attendance of the shareholder near to the usufructuary to the assembly general meeting is under the initiative of the company ${ }^{50}$. The right to attend assembly general meetings is an inalienable right of shareholders (SCO 706b, TCC 447). It cannot be said that TTK 432 II (SCO 690) forecloses this right. This provision also gives the usufructuary the opportunity to attend assembly general meetings, as the voting right can be used in the assembly general meeting ${ }^{51}$. Indeed, this right is also important for shareholders in terms of the use of certain rights that will not be affected by the usufruct on the share. In this respect, even if there is a usufruct on a share, the shareholder who is authorized to attend the assembly general meeting should also be invited to the meeting.

In case it is decided that the voting right will be used by the shareholder, the usufructuary's right to attend assembly general meetings, which is granted to him with an exceptional provision and in connection with the voting right, is eliminated ${ }^{52}$.

\section{Right to Demand Information}

The right to demand information is a wide-ranging concept. It contains three types of informing. Firstly, the company must keep the basic information (annual report and audit report) ready for review by the shareholders (SCO 696, TCC 437 I). This obligation is fulfilled spontaneously by the company without any demand (active information). Apart from that, shareholders may also demand to be informed about certain issues (SCO 697, TCC 437 II IV). In this case, the company becomes obliged to provide information after the demand of the shareholder (passive information). The third type of informing is through special audit (SCO 697a-697g, TCC 438-444). In this way, the balance is redressed between the interest of the shareholder regarding the disclosure of the information and the interest of the company not to disclose the secret information, thanks to the special audit conducted by a third party ${ }^{53}$.

49 Aytaç (n 23) 123; Böckli (n 15) § 12 N 137; Dekker (n 3) Art 690 N 12; Raemy and Gabriel (n 3) Art 690 N 9.

50 Boss (n 3) Art 690 N 9; Länzlinger (n 3) Art 690 N 13.

51 For others who agree with the opinion that shareholders may also attend assembly general meeting, see: Bärtschi (n 23) 337; Reha Poroy, Ünal Tekinalp and Ersin Çamoğlu, Ortaklıklar Hukuku I (13th edn, Vedat 2014) N 679a; Kendigelen (n 3) 326; Teoman (n 14) 375 .

52 For the opinion that in this case, the usufructuary has the right to passive attendance, see: Jung (n 14) Art $625 \mathrm{~N} 67$.

53 BGE 133 III 453 E. 7.2; BGE 140 III 610 E. 2.2; Dekker (n 3) Art 696 N 5; Peter Forstmoser, 'Informations- und Meinungsäusserungsrechte des Aktionärs' in Alain Hirsch, Peter Nobel, Peter Böckli, Peter Forstmoser and Jean Nicolas (eds), Rechtsfragen um die Generalversammlung (Schulthess 1997) 89; Urs Kägi, in Jolanda Kren Kostkiewicz, Stephen Wolf, Marc Amstutz and Roland Fankhauser (eds), OR Kommentar (3rd edn, Orell Füssli 2016) Art 696 N 3, 697 N 2; Peter V. Kunz, 'Das Informationsrecht des Aktionärs in der Generalversammlung' (2001) (8) AJP/PJA 883, 883-884; Raemy and Gabriel (n 3) Art 696 N 1; Rolf H. Weber, in Heinrich Honsell, Nedim Peter Vogt and Rolf Watter (eds), Basler Kommentar: Obligationenrecht II Art. 530-964 OR inkl. Schlussbestimmungen (5th edn, Helbing Lichtenhahn 2016) Art 696 N 1 b. 
The right to demand information is an inalienable right of the shareholder ${ }^{54}$. The feature of this right, which is an independent shareholding right $^{55}$, is to enlighten the shareholder and thus ensure the proper use of other rights. For this reason, this right is in close connection with the rights of shareholders, such as the right to file an annulment, nullity and responsibility action, the right to demand a special audit, and especially the voting right ${ }^{56}$. This right, which has been granted in order to make the voting right effective, is a natural extension of the voting right ${ }^{57}$. Therefore, although there is no clarity on this subject in the law, this right should also be used by the usufructuary when the voting rights belong to him $^{58}$. Otherwise, the usufructuary's ability to fulfill the obligation of careful management may be questioned. Consequently, results that do not comply with the interests of the shareholder may arise, since the voting right cannot be used properly. As the right to demand information is granted to the usufructuary in connection with the voting right, the usufructuary who does not have the voting right shall not have the right to demand information ${ }^{59}$.

However, the use of the right to demand information by the usufructuary does not prevent the shareholder from using $i^{60}{ }^{6}$. Because the acceptance that the shareholder does not have the right to demand information means that the use of this right has been waived by the shareholder with an agreement for establishment of usufruct, this result is contrary to the inalienable character of the right. Furthermore, since the shareholder is given the opportunity to check whether his interests are observed by the usufructuary, the fact that the shareholder has the right to demand information is appropriate to the nature of the usufruct relationship.

The right to demand a special audit should be considered within the scope of the shareholder's right to demand information in a broad sense ${ }^{61}$. Because the shareholder may demand the appointment of a special auditor for clarification of certain issues (SCO 697a, TCC 438). The use of the right to demand information in accordance with the TCC 437 (SCO 696, 697) constitutes a prerequisite for using

54 Felix Horber, 'Das Auskunftsbegehren und die Sonderprüfung - siamesische Zwillinge des Aktienrechts' (1995) (91) SJZ 165, 165; Arslan Kaya, Anonim Ortakllkta Pay Sahibinin Bilgi Alma Hakk (BTHAE 2001) 76 ff; Kunz, 'Informationsrecht' (n 53) 884 .

55 BGE 112 II 147; BGE 109 II 47, 48; Kägi (n 53) Art 697 N 3; Kunz, 'Informationsrecht' (n 53) 884; Weber (n 53) Art 697 N 1.

56 Kaya, Bilgi Alma Hakkı (n 54) 80.

57 Bärtschi (n 23) 337; Teoman (n 14) 372.

58 Aytaç (n 23) 124; Bärtschi (n 23) 337; Boss (n 3) Art 690 N 11; Dekker (n 3 ) Art 690 N 16; Forstmoser, Meier-Hayoz and Nobel (n 3) § 45 N 22; Kaya, Bilgi Alma Hakkı (n 54) 153; Kendigelen (n 3) 322; Länzlinger (n 3) Art 690 N 16; Oğuz (n 16) 40; Raemy and Gabriel (n 3) Art 690 N 12; Reha Poroy, Ünal Tekinalp and Ersin Çamoğlu, Ortaklıklar Hukuku II (13th edn, Vedat 2017) N 974; Teoman (n 14) 372-373; Jung (n 14) Art 625 N 67.

59 For the opposite view, see: Jung (n 14) Art 625 N 67.

60 Aytaç (n 23) 124; Bärtschi (n 23) 337; Boss (n 3) Art 690 N 11; Dekker (n 3) Art 690 N 16; Forstmoser, Meier-Hayoz and Nobel (n 3) § 45 N 22; Kaya, Bilgi Alma Hakk (n 54) 154; Kendigelen (n 3) 323; Länzlinger (n 3) Art 690 N 16; Oğuz (n 16) 40; Poroy, Tekinalp and Çamoğlu, Ortaklıklar Hukuku II (n 58) N 974; Raemy and Gabriel (n 3) Art 690 N 12; Teoman (n 14) 373.

61 Urs Schenker, 'Die Sonderprüfung - ein schwieriges Instrument' (2019) (1) GesKR 18, 19. 
the right to demand a special audit ${ }^{62}$. The right to demand a special audit has been granted to shareholders as an additional opportunity, who think that they have not obtained sufficient information despite using their right to demand information ${ }^{63}$. In this respect, the reasons requiring the right to demand information to be granted to the shareholder as well as the usufructuary are also valid for the right to demand a special audit. The power to manage grants the usufructuary the authority necessary to benefit fully from the usufruct issue. Due to the right to demand a special audit, the usufructuary has the opportunity to realize maximum profit expectation by preventing possible corruption. The usufructuary whose demand for attending a special audit is rejected by the assembly general meeting is also eligible to apply to the court for an auditor appointment provided that he constitutes a minority pursuant to the TCC 439 (SCO 697b).

\section{Right to File an Annulment Action}

There is no doubt that an action for the nullity of the decisions of the assembly general meeting and board of directors, which can be filed by anyone with interest, can also be filed by the usufructuary independent of the voting right.

Who should use the right to file an annulment action is disputable. In doctrine, Okur is of the opinion that the usufructuary does not have the right to file an annulment action, since the usufructuary is not ranked among those who can file an annulment action (SCO 706 I, TCC 446) ${ }^{64}$. Riemer and Tanner argue that the SCO 690 II was regulated under the heading of "Attendance to the assembly general meeting" (OR 689) and this provision does not include the annulment action due to the aforementioned system. Likewise, the voting right and the right to file an annulment action are different rights, and are not connected ${ }^{65}$. Moroğlu suggests that both of them (the usufructuary and the shareholder) are authorized to file an annulment action, the legal nature of the relationship among them is the facultative joinder of parties. The possibility of filing an annulment action constitutes the legal guarantee of the right to attend assembly general meetings and the voting right from the point of the usufructuary, even if the usufructuary is lacking in the voting right, he may file an annulment action just like shareholders without the voting right. Likewise, when the voting right belongs to the usufructuary, the shareholder may use the right to file

62 Arslan Kaya, 'Özel Denetim İsteme Hakkının Bilgi Alma ve İnceleme Hakkı İle İlişkisi' (2015) 31(1) BATİDER 61, 71; Peter V. Kunz, 'Zur Subsidiarität der Sonderprüfung' (1996) (92) SJZ 1, 2 ff ; Poroy, Tekinalp and Çamoğlu, Ortakllklar Hukuku II (n 58) N 1016d; Schenker (n 61) 19 ff.

63 Kaya, 'Özel Denetim' (n 62) 71-72; Schenker (n 61) 19.

64 Yiğit Tahsin Okur, L'action en annulation des décisions de l'assemlée générale des actionnaires dans la société anonyme (Delachaux et Niestlé 1965) 106.

65 Hans M. Riemer, Anfechtungs- und Nichtigkeitsklage im schweizerischen Gesellschaftsrecht (Stämpfli 1998) N 160; Brigitte Tanner, in Lukas Handschin (ed), Zürcher Kommentar Band: Obligationenrecht. Art. 698-726 und 731b OR - Die Aktiengesellschaft (Generalversammlung und Verwaltungsrat, Mängel in der Organisation) (3rd edn, Schulthess 2018) Art 706/ I. - IV. N 48. 
an annulment action (by voting negative and writing the opposition to the protocol according to the Turkish law) as he has the right to attend assembly general meetings. When there is a partial usufruct on the share, both may file an annulment action separately provided that they fulfill the mentioned conditions ${ }^{66}$. In Switzerland and Turkey, the view that the annulment action can be filed by both of them is dominant ${ }^{67}$.

Teoman, on the other hand, states that the voting right and the right to file an annulment action constitute a whole. The usufructuary has to file an annulment action (with the provision to vote negative and write the opposition to the protocol according to the Turkish law) when the interests of the owner require, otherwise he will be responsible to the shareholder. The acceptance that the shareholder is also authorized to file an annulment action may render it meaningless that the voting right is only granted to the usufructuary and it also means that the system accepted by the TCC in terms of the right to file an annulment action would be extended through comments ${ }^{68}$.

When we look at this in practice, in a decision dated 28.5.1981, the Eleventh Civil Department of the Supreme Court of Appeals demonstrated preference on behalf of the last opinion by making a decision that even if there is a partial usufruct on share, the right to file an annulment action would belong to the usufructuary; the shareholder has no right on this subject ${ }^{69}$. In its decision dated 2.6.2015, the Federal Court stated that there was no provision stating that the right to file an annulment action belongs to the usufructuary or the shareholder when the share has a usufruct, and in the article $690 \mathrm{II}$, only a provision regarding the attendance to the assembly general meeting was envisaged ${ }^{70}$. Although it can be accepted that with this decision, the Federal Court holds the opinion that the usufructuary does not have the right to file an annulment action, it would not be wrong to say that the Court did not assert a clear view on this matter.

The fact that the voting right belongs to the usufructuary or the shareholder means that he is authorized to determine the direction of the vote and therefore the will of the company. Acceptance of the right to file an annulment action can be used by both right holders causes the one's voting right to be deactivated by the other through filing an annulment action. As stated, the person who is entitled to use the voting right

66 Erdoğan Moroğlu, Anonim Ortaklıkta Genel Kurul Kararlarının Hükümsüzlüğü (8th edn, On İki Levha 2017) 258 ff.

67 Bärtschi (n 23) 337; Boss (n 3) Art 690 N 11; Dekker (n 3) Art 690 N 16; Forstmoser, Meier-Hayoz and Nobel (n 3 ) § 45 N 22; Jung (n 14) Art 625 N 67; Kendigelen (n 3) 302 ff; Koeferli (n 23) 80; Länzlinger (n 3) Art 690 N 16; Oğuz (n 16) 41-43; Yavuz Okçuoğlu, 'Anonim ve Kooperatif Şirketler Genel Kurul Kararlarının İptali İçin Gerekli Olan Muhalefet ve Muhalefetin Tutanağa Geçirilmesi' in Ticaret Hukuku ve Yargıtay Kararları Sempozyumu II (BTHAE 1985) 279; Poroy, Tekinalp and Çamoğlu, Ortaklıklar Hukuku II (n 58) N 974; Raemy and Gabriel (n 3) Art 690 N 12; Paul Stadlin, 'Über die Rechtsstellung des Eigentümers von in Nutzniessung stehenden Aktien' (1945) 17 SAG 185, 191.

68 Teoman (n 14) 374-375. See for the same view: Halil Arslanl1, Anonim Şirketler II: Anonim Şirketin Organizasyonu (İstanbul Üniversitesi 1959) 77; Aytaç (n 23) 124; Domaniç (n 42) 890.

69 Eleventh Civil Department of the Supreme Court of Appeals, 2243/2768, 28.5.1981; Eleventh Civil Department of the Supreme Court of Appeals, 12676/4234, 29.4.2003 < www.sinerjimevzuat.com.tr > accessed 1.10.2019.

70 BGE 4A_706/2014 E. 3.1. 
is obliged to observe the interests of the other's while using this right. Sanctions on the violation of this obligation are not an invalidation of the vote or the decision of the assembly general meeting, but are the payment of any damages arising from this reason to the other. De lege lata, it is not possible to accept the reasons asserted ${ }^{71}$, in case the other is also entitled to file an annulment action. Occurrence of damage can be prevented and the risk of not compensating the damage can be eliminated. For this reason, the right to file an annulment action should be used only by the person who has the voting right.

\section{Conclusion}

When the subject of the usufruct constitutes a share of a joint stock company, scope of the power to manage, on which property law is based, should be determined by taking into consideration the principles of the company law. Accordingly, the voting right, which is the center of the power to manage, is used by the usufructuary as a rule, and this power of usufructuary also grants him the right to attend assembly general meetings, demand information and file an annulment action. Although there is a significant fracture in the powers of the shareholder against this position of the usufructuary, the shareholder continues to use his rights to attend assembly general meetings and demand information in accordance with the basic principles of the company law.

The shareholder can maintain his authority over the shares subject to usufruct by holding the voting right through an agreement between them. This time, his situation is stronger than the usufructuary who has the voting right, because when the voting right belongs to the shareholder, the usufructuary also loses his right to attend assembly general meetings, demand information and file an annulment action which can be entitled to him due to the voting right. This result does not contradict the power to fully benefit the usufructuary. Because even in this case, the usufructuary continues to benefit from the financial rights provided by the share. And, if the use of management rights by the shareholder damages the power to fully benefit the usufructuary, the shareholder shall be held liable for any loss incurred.

Peer-review: Externally peer-reviewed.

Conflict of Interest: The author has no conflict of interest to declare.

Financial Disclosure: The author declared that this study has received no financial support.

Hakem Değerlendirmesi: Dış bağımsız.

Çıkar Çatışması: Yazar çıkar çatışması bildirmemiştir.

Finansal Destek: Yazar bu çalışma için finansal destek almadığını beyan etmiştir.

71 See Koeferli (n 23) 80; Stadlin (n 67) 191. 


\section{Bibliography}

Arslanlı H, Anonim Şirketler II: Anonim Şirketin Organizasyonu (İstanbul Üniversitesi 1959).

Aytaç Z, Sermaye Piyasası Hukuku ve Hisse Senetleri (BTHAE 1988).

Bärtschi H, 'Pfandrecht und Nutzniessung an Gesellschaftsanteilen' in Peter V. Kunz, Florian S. Jörg and Oliver Arter (eds), Entwicklungen im Gesellschaftsrecht VII (Stämpfli 2012).

Baumann M, 'Nutzniessung und Wohnrecht, Art. 745-778 ZGB' in Peter Gauch and Jörg Schmid (eds), Zürcher Kommentar ZGB Band IV/2a/2 - Das Sachenrecht - Die beschränkten dinglichen Rechte (3rd edn, Schulthess 1999).

Baumann M, Praktische Probleme der Nutzniessung an Aktien, Obligationen und AnlagefondsAnteilscheinen (Schulthess Polygraphischer 1980).

Bichsel M and Mauerhofer K, in Jolanta Kren Kostkiewicz, Stephen Wolf, Marc Amstutz and Roland Frankhauser (eds), ZGB Kommentar (3rd edn, Orell Füssli 2016).

Boss W, in Jolanda Kren Kostkiewicz, Stephen Wolf, Marc Amstutz and Roland Fankhauser (eds), OR Kommentar (3rd edn, Orell Füssli 2016).

Botschaft des Bundesrates an die Bundesversammlung zu einem Gesetzesentwurf über die Revision der Titel XXIV bis XXXIII des schweizerischen Obligationenrechts vom 21. Februar 1928 (BB1 1928 I 205).

Böckli P, Schweizer Aktienrecht mit Fusionsgesetz, Börsengesellschaftsrecht, Konzernrecht, Corporate Governance, Recht der Revisionsstelle und Abschlussprüfung in neuer Fassung unter Berücksichtigung der angelaufenen Revision des Aktien- und Rechnungslegungsrechts (4th edn, Schulthess 2009).

Cramer C, in Lukas Handschin (ed), Zürcher Kommentar: Allgemeine Bestimmungen, Art. 620659b OR Die Aktiengesellschaft (2nd edn, Schulthess 2016).

Domaniç H, Anonim Şirketler Hukuku ve Uygulamast - TTK Şerhi II (Temel 1988).

Dekker S, in Jeannette K. Wibmer (ed), Aktienrecht Kommentar: Aktiengesellschaft, Rechnungslegungsrecht, VegüV, GeBüV, VASR (1st edn, Orell Füssli 2016).

Forstmoser P, Meier-Hayoz A and Nobel P, Schweizerisches Aktienrecht (1st edn, Stämpfli 1996).

Forstmoser P, 'Informations- und Meinungsäusserungsrechte des Aktionärs' in Alain Hirsch, Peter Nobel, Peter Böckli, Peter Forstmoser and Jean Nicolas (eds), Rechtsfragen um die Generalversammlung (Schulthess 1997).

Germann S, Die personalistische AG und GmbH - Unter besonderer Berücksichtigung von Aktionär- und Gesellschafterbindungsverträgen, SSHW Band/Nr. 327 (Dike 2015).

Horber F, 'Das Auskunftsbegehren und die Sonderprüfung - siamesische Zwillinge des Aktienrechts' (1995) (91) SJZ 165-171.

Jung P, in Lukas Handschin (ed), Zürcher Kommentar: Allgemeine Bestimmungen, Art. 620-659b OR Die Aktiengesellschaft, (2nd edn, Schulthess 2016).

Kägi U, in Jolanda Kren Kostkiewicz, Stephen Wolf, Marc Amstutz and Roland Fankhauser (eds), OR Kommentar (3rd edn, Orell Füssli 2016).

Kaya A, Anonim Ortaklıkta Pay Sahibinin Bilgi Alma Hakkı (BTHAE 2001).

Kaya A, 'Özel Denetim İsteme Hakkının Bilgi Alma ve İnceleme Hakkı İle İlişkisi’ (2015) 31(1) BATIDER 61-83.

Kendigelen A, Anonim Ortaklık Payı Üzerinde Intifa Hakkı (1st edn, Beta 1994). 
Kläy H, Die Vinkulierung, Theorie und Praxis im neuen Aktienrecht Helbing \& Lichtenhahn 1997.

Koeferli R, Die Nutzniessung an Wertpapieren unter besonderer Berücksichtigung der Nutzniessung an Aktien (P.G. Keller 1954).

Köprülü B and Kaneti S, Sinırlı Ayni Haklar (Fakülteler Matbaası 1972-1973).

Kunz PV, 'Das Informationsrecht des Aktionärs in der Generalversammlung' (2001) (8) AJP/PJA 883-900.

Kunz PV, 'Zur Subsidiarität der Sonderprüfung' (1996) (92) SJZ 1-5.

Länzlinger A, in Heinrich Honsell, Nedim Peter Vogt and Rolf Watter (eds), Basler Kommentar: Obligationenrecht II Art. 530-964 OR inkl. Schlussbestimmungen (5th edn, Helbing Lichtenhahn 2016).

Moroğlu E, 'Anonim Ortaklıkta Genel Kurul' in Erdoğan Moroğlu (ed), Makaleler (On İki Levha 2010) 291-304.

Moroğlu E, Anonim Ortaklıkta Genel Kurul Kararlarının Hükümsüzlüğü (8th edn, On İki Levha 2017).

Nagel T, 'Die statutarische Vinkulierung nicht kotierter Namenaktien’ (2015) (1) AJP/PJA 191-202.

Oğuzman K, Seliçi Ö and Oktay-Özdemir S, Eşya Hukuku (14th edn, Filiz 2011).

Oğuz A, 'Pay Senetleri Üzerinde İntifa Hakkı Kurulması ve İntifa Hakkının Kapsamı’ (1991) (1) Ankara Barosu Dergisi 23-44.

Okçuoğlu Y, 'Anonim ve Kooperatif Şirketler Genel Kurul Kararlarının İptali İçin Gerekli Olan Muhalefet ve Muhalefetin Tutanağa Geçirilmesi’ in Ticaret Hukuku ve Yargıtay Kararları Sетровуити II (BTHAE 1985).

Okur YT, 'Üzerinde Kısmen İntifa Hakkı Tesis Olunmuş Hisse Senetlerinden Doğan Oy Hakkının Kime Ait Olacağı' (1971) 18(7) İktisat ve Maliye Dergisi 273-278.

Okur YT, 'Hisse Senetleri Üzerinde İntifa Hakk1 Tesisi' (1971) 18(6) İktisat ve Maliye Dergisi 224-229.

Okur YT, L'action en annulation des décisions de l'assemlée générale des actionnaires dans la société anonyme (Delachaux et Niestlé 1965).

Plüss A, in Jeannette K. Wibmer (ed), Aktienrecht Kommentar: Aktiengesellschaft, Rechnungslegungsrecht, VegüV, GeBüV, VASR (1st edn, Orell Füssli 2016).

Poroy R, Tekinalp Ü and Çamoğlu E, Ortaklıklar Hukuku I (13th edn, Vedat 2014).

Poroy R, Tekinalp Ü and Çamoğlu E, Ortaklıklar Hukuku II (13th edn, Vedat 2017).

Raemy Aand Gabriel S, in Vito Roberto and Hans RudolfTrüeb (eds), Handkommentar zum Schweizer Privatrecht Bd. 7: Personengesellschaften und Aktiengesellschaft-Vergütungsverordnung [Art. 530-771 OR und VegüV] (3rd edn, Schulthess 2016).

Riemer HM, Anfechtungs- und Nichtigkeitsklage im schweizerischen Gesellschaftsrecht (Stämpfli 1998).

Schenker U, 'Die Sonderprüfung - ein schwieriges Instrument' (2019) (1) GesKR 18-36.

Stadlin P, ‘Über die Rechtsstellung des Eigentümers von in Nutzniessung stehenden Aktien' (1945) 17 SAG 185.

Tanner B, in Lukas Handschin (ed), Zürcher Kommentar Band: Obligationenrecht. Art. 698-726 und $731 \mathrm{~b}$ OR - Die Aktiengesellschaft (Generalversammlung und Verwaltungsrat, Mängel in der Organisation) (3rd edn, Schulthess 2018). 
Teoman Ö, ‘Anonim Ortaklıkta Paylar Üzerinde İntifa Hakkı Bulunması Durumunda Oy Hakkı Dışındaki Yönetim Haklarının Kimin Tarafından Kullanılacağı Sorunu’ in Ömer Teoman (ed), Tüm Makalelerim, vol. I-II: 1971-2001 (2nd edn, On İki Levha 2012) 365-376.

Thurnherr C, in Peter Breitschmid and Alexandra Jungo (eds), Handkommentar zum Schweizer Privatrecht Bd 3: Sachenrecht Art. 641-977 ZGB (3rd edn, Schulthess 2016).

Ülgen H, 'Anonim Ortaklıklarda Paylar Üzerinde İntifa Hakkı Halinde Oy Hakkının Malik Tarafından Kullanılmasını Öngören Sözleşmelerin Geçerliliği’ (1977) 28(12) İktisat ve Maliye Dergisi 488-495.

Waldburger M, in Vito Roberto and Hans Rudolf Trüeb (eds), Handkommentar zum Schweizer Privatrecht Bd. 7: Personengesellschaften und Aktiengesellschaft-Vergütungsverordnung [Art. 530-771 OR und VegüV] (3rd edn, Schulthess 2016).

Weber W, Das Stimmrecht bei Aktien in Nutzniessung (J. Kalt-Bucher 1927).

Weber RH, in Heinrich Honsell, Nedim Peter Vogt and Rolf Watter (eds), Basler Kommentar: Obligationenrecht II Art. 530-964 OR inkl. Schlussbestimmungen (5th edn, Helbing Lichtenhahn 2016).

Zürcher W, in Jolanda Kren Kostkiewicz, Stephen Wolf, Marc Amstutz and Roland Fankhauser (eds), OR Kommentar (3rd edn, Orell Füssli 2016). 
